\title{
Erratum to: Analysis of early outcome: Burch procedure versus pubovaginal sling
}

\author{
S. P. Marinkovic $\cdot$ H. Mian • M. Evankovich • \\ D. Poplawsky • J. Novi • C. Frey • W. Yap
}

Published online: 1 June 2010

(C) The International Urogynecological Association 2010

Erratum to: Int Urogynecol J

DOI 10.1007/BF01982216

The correct name of the first author is S. P. Marinkovic.

The online version of the original article can be found at http://dx.doi. org/10.1007/BF01982216.

S. P. Marinkovic $\cdot$ H. Mian · M. Evankovich · D. Poplawsky • J. Novi $\cdot$ C. Frey $\cdot$ W. Yap $(\bowtie)$

Department of Urology, Penn State Geisinger Health System,

17822 Danville, PA, USA

e-mail: urourogyn@yahoo.com 